Quim. Nova, Vol. 34, No. 6, 1094-1105, 2011

\title{
O INSTITUTO DE COIMBRA E A ANÁLISE QUÍMICA DE ÁGUAS MINERAIS EM PORTUGAL NA SEGUNDA METADE DO SÉCULO XIX
}

\author{
António José F. Leonardo*, Décio R. Martins e Carlos Fiolhais \\ Departamento de Física e Centro de Física Computacional, Faculdade de Ciências e Tecnologia, Universidade de Coimbra, Rua \\ Larga 3004-516 Coimbra, Portugal
}

Recebido em 9/7/10; aceito em 9/12/10; publicado na web em 29/3/11

\begin{abstract}
THE INSTITUTE OF COIMBRA AND THE CHEMICAL ANALYSIS OF MINERAL WATERS IN PORTUGAL IN THE SECOND HALF OF THE NINETEENTH CENTURY. O Instituto, journal published by the Institute of Coimbra (IC), an academic society founded in this city in 1852, contains many articles on hydrology and chemical analysis of water for human consumption, written by well-known Portuguese chemists and physicians. Based on these papers, we analyse the evolution of hydrology in Portugal throughout the second half of the 19th century, with emphasis on the chemical studies of mineral waters by the physicians Augusto da Costa Simões, Francisco Alves and José Epifânio Marques, and by the chemists Joaquim dos Santos e Silva, António Ferreira da Silva and Charles Lepierre, all of them members of the IC.
\end{abstract}

Keywords: Institute of Coimbra; hydrology; history of chemistry in Portugal.

\section{INTRODUÇÃO}

Ao longo do século XIX ocorreu um desenvolvimento sem precedentes da química analítica, tendo sido estabelecidas as principais técnicas que se mantêm, ainda hoje, pelo menos nos seus fundamentos.

O reconhecimento social desta área da Química foi obtido graças a crescentes preocupações com a higiene e a saúde públicas, a rentabilização de processos agrícolas e industriais, a investigação forense e a hidrologia, entendida como o estudo das diferentes espécies de águas e das suas propriedades, assim como a respectiva distribuição geográfica. Em particular, a questão da salubridade da água para consumo humano desencadeou numerosos estudos sobre as águas de fontes, rios, nascentes e lagos. A classificação destas diferentes águas foi determinante não só para a selecção de fontes para o abastecimento público, mas também para a valorização de águas com características benéficas para a saúde. Com efeito, a partir de meados do século XIX começaram a ser definidos os principais parâmetros físicos, químicos e biológicos para avaliar a potabilidade da água e prever os seus efeitos fisiológicos, que interessam para a sua adopção como agente terapêutico. Ao longo da história tinham surgido um pouco por todo o mundo balneários, caldas ou termas que reclamavam efeitos curativos ou mesmo milagrosos. Embora a designação original de "água termal" se refira à sua temperatura (superior a $25^{\circ} \mathrm{C}$ ), os efeitos terapêuticos não se restringiam à sua acção térmica, reconhecendo-se que as qualidades da água tinham a ver com a composição química. A procura cada vez maior das estâncias termais suscitou a criação da hidrologia médica, a área da medicina que procura estabelecer relações entre as qualidades de uma água termal e a sua acção fisiológica.

Neste estudo, depois de apresentarmos brevemente a história das águas minerais e da sua análise química no mundo e em Portugal, analisamos os trabalhos de hidrologia médica ao longo da segunda metade do século XIX que foram reportados pela revista $O$ Instituto,

\footnotetext{
*e-mail: ajleonardo@iol.pt
}

o órgão da academia dos lentes da Universidade de Coimbra, que é a mais antiga universidade portuguesa e que foi a única nessa época.

\section{AS ÁGUAS MINERAIS E A SUA ANÁLISE QUÍMICA}

Águas minerais são águas que ocorrem naturalmente em certos locais e que possuem constituintes minerais, conferindo-lhes sabor próprio e/ou valor terapêutico. As fontes de águas minerais passaram a ser alvo de grande interesse a partir do momento em que lhes foram associadas acções terapêuticas. A fama assim granjeada era, muitas vezes, baseada em crenças e superstições, bem arreigadas nas populações, sendo as qualidades curativas realçadas por histórias ou lendas que ajudavam para estimular a procura.

Datam do século XVII os primeiros estudos sobre a composição de águas minerais, alguns dos quais provenientes de médicos ao serviço de estâncias termais. ${ }^{1}$ Destacam-se os trabalhos dos franceses Samuel Cottereau Duclos (1598-1685) e Claude Bourdelin (162199) a partir de 1670, ambos na recém-fundada Academia Real das Ciências de Paris (1666), do inglês Robert Boyle (1627-91) e do alemão Friedrich Hoffmann (1660-1742). Estes dois últimos escreveram livros sobre a experimentação com águas minerais. ${ }^{2}$ Hoffmann propôs um conjunto de testes para identificar águas ferruginosas, calcáreas e sulfurosas, tendo também por objectivo a produção de águas artificiais. ${ }^{3}$

A partir do século XVIII, novos métodos de análise química contribuíram para alterar o paradigma nesta área. A proliferação de embustes e a ineficácia na acção médica de muitas águas que, para além do efeito placebo, poucos ou nenhuns resultados produziam, geraram enorme desconfiança. Tornou-se então necessário explicar as características benéficas das águas minerais a partir dos seus constituintes, fornecendo uma prova científica das propriedades curativas na qual se pudesse basear a prosperidade de uma estância termal.

As características físicas e químicas das águas minerais eram extremamente variadas, tal como os seus efeitos médicos. Apesar da falta de acordo relativamente aos seus componentes, essas águas eram, no início do século XIX, genericamente classificadas em sul- 
furosas, salinas, férreas e carbonatadas. De maior complexidade era o problema de estabelecer elos causais entre determinado constituinte e o efeito terapêutico da água. Muitos consideravam que a análise das águas minerais era "a operação mais difícil em química". ${ }^{4}$

O trabalho do sueco Torbern Bergman (1735-84) sobre as afinidades de ácidos e bases e na sua capacidade de se substituírem em sais e precipitarem foi um marco na História da Química. ${ }^{5}$ Esse autor publicou em 1778 um conjunto de artigos apresentando um sistema de análise de águas com três componentes: o exame das propriedades físicas, o estudo qualitativo dos componentes com recurso a reagentes indicadores, e a análise quantitativa da composição do resíduo obtido por evaporação da água. ${ }^{6}$ A observação das características físicas das águas remontava à Antiguidade, tendo oscilado nos parâmetros observados e na precisão dos instrumentos usados, designadamente o termómetro ou a balança (para medir massas volúmicas). Vários métodos de análise qualitativa, designadamente recorrendo a reagentes para detectar determinadas substâncias, foram descobertos ao longo do século XVII, durante o período da iatroquímica, sendo muitos indicadores colorimétricos definidos por Boyle. Contudo, estes testes foram secundarizados em relação aos métodos quantitativos, em virtude da sua incerteza e da ignorância do mecanismo subjacente à sua acção. Assim, a análise da composição do resíduo revelava-se essencial para aquilatar a real composição da água mineral. Todavia, além das dificuldades inerentes à análise do resíduo sólido, um outro problema permanecia. A sua resolução só se tornou possível após a teoria de dissociação do químico sueco Svante Arrhenius (1859-1927) na década de $1890 .^{7}$ Um obstáculo aparentemente incontornável resultava do facto de os sais detectados no resíduo seco, obtido após evaporação, não serem, necessariamente, os mesmos que existiam em fase aquosa. Durante o processo de aquecimento e de cristalização alteravam-se os compostos preexistentes na água mineral, tornando impossível o conhecimento dos componentes originais. Uma destas alterações veio a ter uma explicação: a libertação do dióxido de carbono pela água agitada ou aquecida, uma das características evidenciadas pelas águas carbonatadas. Medindo a quantidade de gás libertado foi possível calcular os respectivos sais carbonatados presentes em solução e corrigir a alteração ocorrida, estabelecendo a diferença entre a dureza temporária e a dureza permanente. ${ }^{8}$ Esta demonstração estabeleceu que, mesmo que a análise alterasse os constituintes da água mineral, os químicos poderiam, mais tarde, efectuar as necessárias correcções.

Uma explicação mais abrangente, que englobava os restantes sais, foi dada em 1815 pelo químico escocês John Murray (1778-1820). Este professor de Matéria Médica e Farmácia da Universidade de Edimburgo esclareceu a impossibilidade de determinar as combinações das bases e ácidos presentes ao propor que os sais obtidos na análise, durante a formação do resíduo sólido, não eram exactamente os mesmos que estavam presentes na solução diluída. Tal asserção era comprovada pela aparente impossibilidade de sintetizar uma dada água mineral artificial pela dissolução dos sais existentes no respectivo resíduo sólido. Acreditava-se que as operações analíticas alteravam a combinação de ácidos e bases, podendo alguns deles "trocar de parceiros" durante a evaporação do solvente. Inclusivamente, desconhecia-se se os ingredientes salinos nas águas minerais se encontravam em combinações binárias entre ácidos e bases ou se interagiam simultaneamente de forma a neutralizar toda a solução. Não havia maneira de dizer, com certeza, se uma certa água era rica em cloreto de cálcio e sulfato de sódio ou em cloreto de sódio e sulfato de cálcio. Uma forma de minimizar as incertezas seria efectuar a determinação de cada uma destas espécies minerais sem considerar as suas possíveis combinações. Estes resultados não satisfaziam, porém, as exigências dos proprietários de estâncias termais, uma vez que os médicos estavam convencidos de que os ingredientes terapêuticos activos numa água mineral eram os sais e não os respectivos ácidos ou bases. Assim, de acordo com as suas afinidades ou considerando as solubilidades dos sais respectivos, estimavam-se as combinações em que estes estariam em solução. ${ }^{9}$

A análise das águas minerais proporcionou uma luta entre a Medicina e a Química, reivindicando cada uma delas a última palavra. A prescrição por um médico de um tratamento por determinada água mineral baseava-se, inicialmente, em relatos dos seus efeitos terapêuticos. Inclusivamente, a descoberta de novas águas minerais e a inauguração de estâncias termais não dependia de qualquer análise química, mas sim da cura de maleitas específicas. Contudo, era imprescindível obter alguma forma de legitimação das propriedades curativas, conferindo credibilidade ao produto ou serviço oferecido. Uma maneira seria através de ensaios clínicos que comprovassem determinados efeitos terapêuticos. Outra possibilidade era a descoberta e/ou detecção dos agentes químicos responsáveis pelos efeitos médicos, como foi o caso do iodo detectado em algumas fontes em meados do século XIX..$^{10}$ Adicionalmente, o conhecimento da concentração de determinado agente permitiria estabelecer o período de tratamento apropriado a cada doente.

Procurava-se através da análise das águas minerais dar uma legitimação científica às qualidades anunciadas pelos proprietários das estâncias. Embora os resultados não garantissem as reais quantidades de sais existentes nem a sua correlação com a acção fisiológica, a publicidade era eficaz. A aura de modernidade que envolvia a nova ciência química, talvez ainda com alguns resquícios de espiritualidade e magia da alquimia, exercia um enorme poder persuasor sobre o público, em particular as classes mais abastadas. Por conseguinte, "o acto solene da iniciação de uma água mineral, realiza-se pela Química”. É ela "que dá foros de nobreza a uma nascente". ${ }^{11}$

Uma outra razão relacionava-se com a possibilidade de produzir imitações. A obtenção artificial de uma água mineral, reproduzindo ou mesmo amplificando as suas propriedades terapêuticas ao mesmo tempo que se eliminavam supostos efeitos secundários, surgia como uma possibilidade atractiva. Obviamente, estas tentativas viram-se frequentemente frustradas dadas as já referidas restrições dos processos analíticos, dando razão àqueles que defendiam a singularidade das fontes naturais.

\section{O ESTUDO DAS ÁGUAS MINERAIS EM PORTUGAL}

As primeiras estâncias termais em Portugal remontam ao período romano. O médico "estrangeirado" Jacob Castro Sarmento (16911762), no seu livro Matéria médica (1735), abordou as águas minerais, descrevendo algumas águas de Inglaterra, Alemanha e Portugal, e referiu a antiguidade da sua aplicação, embora afirmasse que "sobre os seus princípios não encontramos mais do que especulações imaginárias, fantasias fabulosas”. Em 1758, o Marquês de Pombal enviou um questionário aos párocos onde os interrogava sobre "se há no seu distrito algumas fontes de propriedades raras?". ${ }^{12}$

As primeiras análises químicas de águas minerais em Portugal terão sido realizadas no Laboratório Chimico da Universidade de Coimbra (UC) nas últimas décadas do século XVIII, sob a orientação de Domingos Vandelli (1739-1816), químico e naturalista italiano contratado pelo Marquês de Pombal. Vandelli e os seus discípulos, nomeadamente os portugueses José Martins da Cunha Pessoa (17451822) e João Nunes Gago (1743-1819), efectuaram entre 1775 e 1781 análises das águas do Estoril e das Caldas da Rainha. ${ }^{13}$ Todavia, os processos adoptados eram muito imperfeitos no que respeita à química, uma vez que as ideias de Lavoisier só se tornaram conhecidas em Portugal após a publicação dos Elementos de Chimica, do brasileiro Vicente Coelho de Seabra Telles (1764-1804), entre 1788 e 1790. Em 1791, Francisco Tavares (1750-1812), lente de Medicina da 
Universidade de Coimbra publicou, nas Memórias da Academia das Ciências de Lisboa, as "Advertencias sobre os abusos, e legitimo uso das aguas mineraes das Caldas da Rainha, para servir de Regulamento aos enfermos que dellas tem precisão real."

A preocupação pela análise química em Portugal foi também uma consequência da recepção das teorias do médico holandês Hermann Boerhaave (1668-1738), em oposição à medicina humoral de Hipócrates e Galeno, após a reforma da UC em 1772. Assim, ao considerar a saúde como dependente do "movimento regular dos fluidos", as propriedades medicinais dos remédios deixavam de ser "virtudes occultas" mas consequências das suas características físico-químicas. ${ }^{14}$

$\mathrm{O}$ estudo das águas minerais sofreu um grande impulso ainda na primeira metade do século XIX pelo reconhecimento de "que Portugal era talvez o país da Europa onde proporcionalmente ao seu território havia maior quantidade de águas minerais", ${ }^{15}$ apesar de se ignorarem as suas propriedades e aplicações. $\mathrm{O}$ valor deste recurso natural conduziu à deliberação pelo Parlamento, em 1822, de efectuar um inventário rigoroso das águas minerais do reino, tendose verificado que apenas existia um catálogo elaborado em 1726 por Francisco da Fonseca Henriques (1665-1731), médico do rei D. João $\mathrm{V}$, com o título de Aquilegio Medicinal (do Dr. Mirandela - como ficou conhecido Fonseca Henriques, que era natural desta localidade). Este inventário pouco rigoroso foi reformulado, em 1810, por Tavares, no seu livro Instrução e cautelas práticas sobre natureza, diferentes espécies, virtudes em geral e legítimo uso das águas minerais... mais conhecidas em cada uma das províncias do reino de Portugal, onde o autor excluiu águas sem virtudes curativas e acrescentou outras entretanto descobertas. $\mathrm{O}$ autor descreveu, de forma mais exacta, os efeitos terapêuticos e as qualidades físicas e químicas dessas águas, ao mesmo tempo que refutava os argumentos pouco ou nada científicos e as qualidades milagrosas que eram atribuídas pelo povo a algumas águas. Este trabalho surgiu em resposta às críticas que haviam sido formuladas à omissão da parte química na sua primeira memória de 1791. ${ }^{16}$ Contudo, Tavares esclareceu que, apesar dos entusiasmos pelas análises químicas que inebriavam muitos espíritos do tempo, não era nelas que se baseava o conhecimento médico das águas minerais, em particular os seus efeitos terapêuticos, mas sim nas observações clínicas atentas e criteriosas. ${ }^{17}$

Foi também citado, na publicação de 1810 , o estudo A chemical analysis of the water at Caldas da Rainha, realizado em 1793 pelo inglês William Withering (1741-99), sócio da Academia Real das Ciências de Lisboa e da Royal Society de Londres. ${ }^{18}$ Este trabalho foi considerado "a primeira e verdadeiramente scientifica analyse que se fez das aguas mineraes portuguezas". ${ }^{19}$ A 22 de julho de 1822, o Barão de Molelos, Francisco de Paula Tovar (1774-1852), apresentou numa sessão das Cortes uma proposta para se levantar um inventário definitivo das águas minerais do reino. Esse trabalho deveria incluir análises químicas que colmatassem as deficiências dos trabalhos anteriores. Embora o governo dessa época tivesse logo anuído e ordenado aos corregedores das comarcas que procedessem às necessárias diligências, a escassez de pessoas habilitadas e as perturbações políticas da época impediram a conclusão de tal empreitada. No Jornal da Sociedade Farmacêutica Lusitana foram publicadas, em 1839, análises de várias águas em virtude de uma portaria que mandatou esta sociedade para o estudo das águas minerais do reino.

\section{O INSTITUTO E A HIDROLOGIA EM COIMBRA}

Em 1852, foi fundada em Coimbra, em ligação estreita com a UC, a sociedade científica e literária $O$ Instituto (IC) que, ao longo da sua história, teve como associados proeminentes académicos nacionais assim como reputadas individualidades estrangeiras. No mesmo ano, esta academia iniciou a publicação de uma revista científica e literária reunindo artigos produzidos pelos seus sócios. Adoptando o nome da associação que lhe deu origem, essa publicação, $O$ Instituto, manteve-se até 1981 , perfazendo 141 volumes que são hoje uma ferramenta indispensável para a história da ciência em Portugal. ${ }^{20}$ Nela foram publicados vários artigos que abordam a análise química das águas minerais.

Dois episódios relacionados com análise química das águas merecem um destaque particular, designadamente a fundação dos Banhos do Luso e o abastecimento de água a Coimbra. A abordagem científica destes dois empreendimentos, cujos contornos foram revelados n' $O$ Instituto, incentivou a emergência da hidrologia em Coimbra.

António Augusto da Costa Simões (1819-1903), professor da Faculdade de Medicina da Universidade de Coimbra e sócio efectivo do IC, aliou às suas funções de professor e médico outras na área da química. Logo nos primeiros volumes d'O Instituto, Costa Simões foi autor de vários artigos onde descreveu as análises realizadas no Laboratório Chimico da UC no âmbito da química forense. ${ }^{21} \mathrm{Um}$ assunto de interesse para Costa Simões foi a análise de águas dos Banhos do Luso, ${ }^{22}$ dos quais foi o primeiro dinamizador, movido talvez pelo facto de ser natural da Mealhada, perto do Luso. Num conjunto de artigos dedicados a este tema descreveu a topografia e a geologia da serra do Buçaco e incluiu uma análise qualitativa das águas do Luso. ${ }^{23}$

As características físicas das águas do Luso foram analisadas por Costa Simões em 27 de junho de 1851, medindo a quantidade de água debitada, a sua temperatura e densidade. Quanto às suas características químicas, usando a tintura e o papel de tornesol, demonstrou o seu carácter ácido, além de ter detectado ácido carbónico, ácido sulfídrico, carbonatos, sulfuretos, cloretos e vestígios de magnésia, alumina e soda. Inferiu a presença de carbonatos e ácido carbónico a partir da efervescência produzida durante a adição de ácido clorídrico. Os sulfuretos e cloretos foram detectados por métodos gravimétricos: com adição de acetato de chumbo observou-se a formação de cristais escuros nas paredes do reservatório, presumivelmente sulfureto de chumbo; a adição de nitrato de prata tornou a solução "leitosa", devido à formação de cloreto de prata, originando posteriormente um precipitado escuro que se suspeitou ser sulfureto de prata; juntando sulfato de cobre (II) verificou-se a formação de sulfureto de cobre. ${ }^{24}$

Com base no conteúdo mineral da água do Luso, Costa Simões descreveu os seus efeitos fisiológicos, salientando as suas qualidades de água termal. Estudou os seus efeitos higiénicos e a relação entre os princípios mineralizadores e os seus efeitos curativos de "moléstias" cutâneas, oftalmológicas e internas. Os relatórios da Sociedade de Banhos de Luso, que passaram a ser publicados n'O Instituto, incluíam uma estatística médica em que eram referenciadas as doenças das pessoas que frequentavam os Banhos e os números de curas, melhoras ou pessoas "no mesmo estado". Em 1860 repetiram-se as análises das águas do Luso, desta vez em Paris, por Matias de Carvalho e Vasconcelos (1832-1910), um docente da Faculdade de Filosofia da UC que aí se encontrava em missão científica.

Nessa mesma época, o cirurgião Abel Maria Dias Jordão (183374), na sua tese de doutoramento submetida à Faculdade de Medicina da Universidade de Paris em 1857, dissertou sobre um caso de diabetes e, verificando-se que era recomendado o uso terapêutico de águas ferruginosas a estes doentes, indicou no final do seu trabalho um conjunto de análises químicas por ele realizadas de várias águas da serra de Monchique e das proximidades e Lisboa. Um exemplar do livro publicado foi oferecido ao IC. ${ }^{25}$

Em 1860 foi criado, na Faculdade de Medicina da UC, um Gabinete Químico destinado a análises toxicológicas, que possuía uma vasta colecção de reagentes e instrumentos. ${ }^{26}$ Francisco António Alves (1832-1873), lente de Anatomia Patológica e Toxicologia da UC, 
fundador do gabinete de Anatomia Patológica e também sócio do IC, aproveitando os recursos deste gabinete, iniciou estudos analíticos das águas de Coimbra a fim de detectar a sua potabilidade (Figura 1). Os resultados desses estudos foram publicados em 1862 n'O Instituto sob o título de Hidrologia. ${ }^{27}$ Alves salientou a importância da hidrologia sob o ponto de vista terapêutico e de higiene pública, afirmando: "oxalá se desse a este objecto toda a attenção de que elle carece, $e$ de que se torna tão digno!”. ${ }^{28}$ As análises que realizou incidiram nas águas do rio Mondego e de mais cinco fontes da cidade de Coimbra. Restringiram-se à determinação qualitativa de "saes terrosos", com a aplicação de reagentes sobre água fervida e filtrada e depois levada à ebulição, e à determinação dos graus "hydrotimétricos" de ácido carbónico, de sais de magnésia e de sais de cal (dureza da água). ${ }^{29}$

As águas do Luso foram também analisadas por Alves alguns anos mais tarde. Os resultados foram, uma vez mais, publicados n' $O$ Instituto em 1872, num trabalho mais extenso do que os anteriores. Para além das análises gravimétricas das amostras originais, repetidas numa segunda amostra, obtida após dissolução do resíduo sólido em água destilada, o autor aplicou os novos métodos espectroscópicos por meio da análise espectral da chama produzida pelo resíduo sólido num bico de Bunsen, tendo detectado sódio e potássio. Estes resultados foram confrontados com outros realizados em amostras colhidas em anos anteriores por Costa Simões e preservadas em "garrafas bem tapadas". ${ }^{30}$ Alves qualificou as águas do Luso como "bicarbonatadas sódicas", de acordo com a classificação então adoptada por muitos hidrologistas. Seguiu-se a análise quantitativa com base na quantidade de precipitado obtido nos vários testes, indicando num primeiro quadro as quantidades de ácidos e bases (aniões e catiões), nomeadamente o ácido sulfúrico (sulfatos), o cloro (cloretos), o ácido carbónico (carbonatos), a cal (cálcio), o potássio, o sódio, etc. Posteriormente, foram calculadas as quantidades dos respectivos sais em solução, estabelecendo as combinações entre as quantidades equivalentes de ácidos e bases, e a composição dos gases dissolvidos. Para finalizar, Alves apresentou um quadro comparativo da água do Luso com outras águas minerais, tanto nacionais como estrangeiras.
Tendo sido, entre 1856 e 1857, presidente da Câmara Municipal de Coimbra, Costa Simões iniciou em 1865 o projecto de abastecimento público de água em Coimbra, ${ }^{31}$ com origem em captações e elevações a partir do rio Mondego. Mais tarde, veio a publicar no mesmo jornal um estudo pormenorizado das águas públicas de Coimbra, onde incluiu alguns mapas das análises efectuadas por Alves.

Nos artigos com o título Abastecimento d'Águas em Coimbra, Costa Simões relatou, em pormenor, todo o processo de desenvolvimento deste empreendimento. Destaca-se a preocupação demonstrada na avaliação da qualidade da água, fazendo depender esta do seu "arejamento" e conteúdo mineral, dentro de certos limites. Baseando-se no Traité d'hygiène, de Adrien Proust (1834-1903), ${ }^{32}$ publicado em 1881 , salientou a utilidade dos sais minerais nos processos nutritivos e de crescimento humano, em particular a sílica, o carbonato de cálcio e o cloreto de sódio. Alertou para o facto de as canalizações serem de chumbo, o que poderia originar a formação de compostos desse metal devido ao seu contacto continuado com a água. Divulgou estudos com água destilada em contacto com chumbo na presença de ar, onde verificou a formação de hidrogenocarbonatos de chumbo, mas acrescentou que este efeito se atenuava em função da dureza da água, bastando uma pequena percentagem de sais calcários, como o carbonato de cálcio e o sulfato de cálcio, para praticamente o eliminar. Costa Simões explicou esta situação com a formação de "incrustações de carbonato de cal nas paredes dos tubos, e que além d'isso differentes carbonatos e sulphatos, em combinação com o oxydo de chumbo, também ali ficam adherentes em camada ou revestimento insolúvel". ${ }^{33}$ Seria também imprescindível a inexistência na água de nitratos ou acetatos, substâncias que poderiam favorecer as reacções de formação de compostos de chumbo. Contudo, recomendou a utilização de tubos de ferro na canalização dos hospitais da Universidade, uma vez que o seu custo não excedia muito o dos tubos de chumbo. Aconselhou também o uso do ferro na construção dos reservatórios pois considerou que o contacto da água "com este metal, ainda que oxydado, não adquire qualidades nocivas, se não houver grande desleixo na sua limpeza de tempos a tempos" ${ }^{34}$ Ensaiou uma estimativa

\section{Mappa dos grans hydrotimetricos da agua no estado natural o depois de snjeita às operaçōes abaizo mencionadas}

\begin{tabular}{|c|c|c|c|c|c|c|c|}
\hline \multirow[b]{2}{*}{ Designaçăo das aguas } & \multirow{2}{*}{ 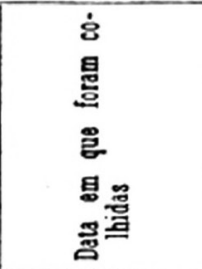 } & \multirow[b]{2}{*}{ 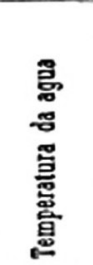 } & \multirow[b]{2}{*}{ 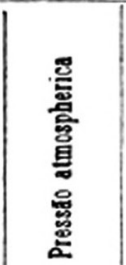 } & \multicolumn{4}{|c|}{ Grau bydrotimetrico da agua } \\
\hline & & & & 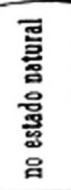 & 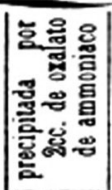 & 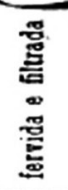 & 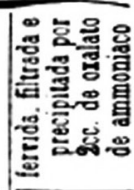 \\
\hline Agua do Mondego $\ldots \ldots \ldots \ldots \ldots \ldots \ldots \ldots$ & $\begin{array}{c}2 \text { de fevereiro } \\
\text { de } 1862\end{array}$ & $12 \circ \mathrm{c}$. & $750 \mathrm{mil}$. & $12^{\circ}$ & 90 & $8^{\circ}$ & $7^{\circ}$ \\
\hline Agua da fonte da Feira $\ldots \ldots \ldots \ldots \ldots \ldots \ldots \ldots \ldots \ldots \ldots$ & idem & $12^{\circ} \mathrm{c}$ & idem & $299^{\circ}$ & $17^{\circ}$ & $13^{\circ}$ & 13. \\
\hline 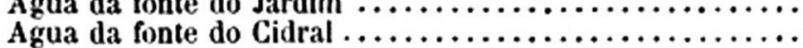 & $\begin{array}{l}\text { ae revereiro } \\
\text { idem }\end{array}$ & $12^{\circ} \mathrm{c}$. & $\begin{array}{l}\text { Ioem } \\
\text { idem }\end{array}$ & $19^{\circ}$ & $10^{\circ}$ & $10^{\circ}$ & 80 \\
\hline 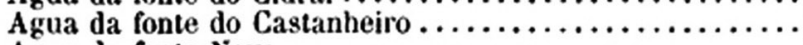 & 5 de fevereiro & $13^{\circ} \mathrm{c}$. & idem & $12^{\circ}$ & 70 & $8^{\circ}$ & $6^{\circ}$ \\
\hline Agua da fonte Nova.$\ldots \ldots \ldots \ldots \ldots \ldots \ldots \ldots \ldots \ldots \ldots$ & 4 de fevereiro & $12^{\circ} \mathrm{c}$ & idem & $95^{\circ}$ & $52^{\circ}$ & $42^{\circ}$ & $37^{\circ}$ \\
\hline Agua da fonte das Lagrimas..$\ldots \ldots \ldots \ldots \ldots \ldots \ldots$ & 23 de abril & $18^{\circ} \mathrm{c}$ & $753 \mathrm{mil}$. & $30^{\circ}$ & $16^{\circ}$ & $16^{\circ}$ & $14^{\circ}$ \\
\hline Agua da fonte de Cellas $\ldots \ldots \ldots \ldots \ldots \ldots \ldots \ldots \ldots \ldots$ & 25 de abril & $17^{\circ} \mathrm{c}$. & $752 \mathrm{mil}$. & $25^{\circ}$ & $16^{\circ}$ & $17^{\circ}$ & $14^{\circ}$ \\
\hline Agua da cisterna da Universidade $\ldots \ldots \ldots \ldots \ldots \ldots \ldots$ & 4 de majo & $16^{\circ} \mathrm{c}$ & idem & $11^{\circ}$ & $6^{\circ}$ & $7^{\circ}$ & $5^{\circ}$ \\
\hline 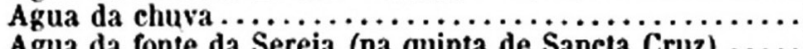 & idem & $13^{\circ} \mathrm{c}$. & idem & 90 & $\begin{aligned} 3^{\circ} \\
16^{\circ}\end{aligned}$ & $22^{0}$ & $\begin{aligned} 2 \circ \\
1\end{aligned}$ \\
\hline $\begin{array}{l}\text { Agua da fonte da Sereia (na quinta de Sancta Cruz) } \ldots \ldots \\
\text { Agua d'um poco do bairro baixo (rua da Louca) } \ldots \ldots \ldots \text {. }\end{array}$ & 5 de maio & $17 \bullet \mathrm{c}$ & idem & $\begin{aligned} 27^{\circ} \\
90^{\circ}\end{aligned}$ & $16^{\circ}$ & $17^{\circ}$ & $15^{\circ}$ \\
\hline $\begin{array}{l}\text { Agua d'um poço do bairro baıxo (rua da loufa) } \ldots \ldots \ldots \\
\text { Agua d'um poço no bairro baixo (largo das Ameias) } \ldots \ldots\end{array}$ & $\begin{array}{l}7 \text { de maio } \\
\text { jdem }\end{array}$ & $\begin{array}{l}10^{\circ} \mathrm{c} . \\
16^{\circ} \mathrm{c} .\end{array}$ & $\begin{array}{l}\text { 153 mil. } \\
\text { idem }\end{array}$ & $15^{\circ}$ & $10^{\circ}$ & 110 & 9. \\
\hline 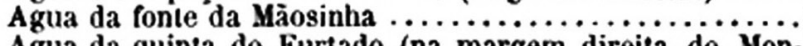 & 8 de maio & $17^{\circ} \mathrm{c}$. & idem & $\mathbf{9}^{\bullet}$ & $6^{\circ}$ & $5^{\circ}$ & $5^{\circ}$ \\
\hline 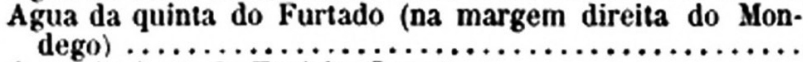 & idem & $17^{\circ} \mathrm{c}$ & idem & $16^{\circ}$ & $11^{\circ}$ & $11^{\circ}$ & $10^{\circ}$ \\
\hline Agua da fonte do Espirito Sancto $\ldots \ldots \ldots \ldots \ldots \ldots \ldots$ & 9 de maio & $17^{\circ} \mathrm{c}$ & jdem & $17 \circ$ & $11^{\circ}$ & $12^{\circ}$ & $10^{\circ}$ \\
\hline Agua do convento de & idem & 1700 & idem & $24^{\circ}$ & $16^{\circ}$ & $18^{\circ}$ & $15^{\circ}$ \\
\hline
\end{tabular}

Figura 1. Mapa dos graus hidrométricos determinados na análise de Francisco Alves das águas de Coimbra em $1862^{33}$ 
do consumo médio em Coimbra em comparação com os valores de cidades europeias como Londres, Nancy, Paris, Roma e Marselha. Numa segunda parte do artigo relatou as dificuldades que retardaram o abastecimento de águas e a sua intervenção ao longo deste processo.

\section{UM NOVO ÍMPETO NO ESTUDO DAS ÁGUAS MINERAIS}

Após um período de estagnação, apenas em 1860, pela portaria de 10 de março, se retomou o interesse pelo estudo das águas minerais em Portugal efectivado pelo envio, a todos os governadores de distrito, de um questionário, que deveria ser encaminhado "às pessoas competentes", sobre um conjunto de quesitos relativos às qualidades químicas e físicas das fontes, bem como das suas características terapêuticas. Uma vez mais, este intento esbarrou com a ineficiência dos serviços públicos portugueses, tendo apenas alguns governadores dado cumprimento integral da referida portaria e, ainda assim, com algumas deficiências nos esclarecimentos prestados. ${ }^{35}$ Em 13 de outubro de 1866 foi nomeada uma comissão, presidida por Tomaz de Carvalho (1819-97), doutorado em Medicina em Paris e director da Escola Médico-Cirúrgica de Lisboa, para proceder a estudos de hidrologia. Um membro desta comissão foi Agostinho Vicente Lourenço (1826-93), ${ }^{36}$ proeminente químico de origem goesa que trabalhou nos mais importantes laboratórios europeus, nomeadamente em colaboração com Adolphe Wurtz (1817-84), em Paris, com Justus von Liebig (1803-73), em Munique, Robert Wilhelm Bunsen (1811-99), em Heidelberg, na Alemanha, e com August Wilhelm von Hofmann (1818-92) em Londres. ${ }^{37}$ As análises que efectuou a numerosas águas minerais portuguesas foram compiladas num relatório intitulado Trabalhos preparatorios ácerca das aguas minerais do Reino e providencias do Governo sobre proposta da Commissão respectiva, publicado em 1867. Nesse mesmo ano, Lourenço organizou uma colecção de amostras das águas minerais portuguesas, recolhidas em todo o país, catalogadas em frascos devidamente etiquetados, onde "foi declarada a natureza de cada uma das águas, segundo a moderna nomenclatura que a analyse exprimia". ${ }^{38}$ Esta colecção integrou o trabalho Renseigments sur les eaux minerales portugaises, que foi premiado na Exposição Internacional de Paris desse ano com uma medalha de ouro.

A primeira tese realizada por um português envolvendo o tema da hidrologia e das águas minerais foi publicada em 1867 pelo farmacêutico António Alves Ferreira, da Escola de Farmácia da Grã-Bretanha e da Escola de Medicina e Farmácia do Rio de Janeiro, cidade onde residia apesar de ser natural do Porto. Tratou-se de uma dissertação doutoral em ciências apresentada à Universidade de Bruxelas e intitulada Hydrologie Générale ou dissertation sur la Nature, les qualités e les usages des eaux naturelles e artificielles, minérales e potables, ${ }^{39}$ uma obra exemplar do estudo de tudo o que se relacionava com as águas minerais. A primeira parte incidiu nas considerações gerais sobre águas e a hidrologia e a segunda parte nos aspectos químicos da água pura e nas suas propriedades. A terceira parte foi dedicada às águas potáveis naturais, analisando na parte seguinte as águas minerais ou medicinais naturais. Abordou, em pormenor, as suas propriedades físicas e organolépticas e a sua mineralização, com base na qual avançou uma classificação em águas minerais: aciduladas ou gasosas, alcalinas, salina, ferruginosas e sulfurosas, apresentando exemplos internacionais mas também portugueses (como foi o caso das águas das Caldas da Rainha), indicando as respectivas composições com base nas mais recentes análises (citando as análises realizadas por Abel Jordão em 1857) e terminando essa parte com a sua acção fisiológica e terapêutica e a sua administração médica. Numa quinta parte explorou o tema das águas artificiais, descrevendo métodos de fabrico e algumas fórmulas de água mais conhecidas. A sexta e última parte tratou a análise química (qualitativa e quantitativa), sendo mencionada a análise espectral, onde se incluem os espectros de alguns elementos. Tendo sido publicada em Paris, não terá sido grande a sua repercussão em Portugal. No entanto, esta obra, que revela um conhecimento apurado de Alves Ferreira no tema, é um marco na história da análise das águas minerais.

Em 1871, a Imprensa da Universidade de Coimbra publicou uma monografia que analisava as águas minerais de Moledo sob o ponto de vista da sua composição química, acção fisiológica e efeitos terapêuticos. Da autoria de Miguel Leite Ferreira Leão (1815-80), então director do Laboratório Chimico, e de dois professores da Faculdade de Medicina, o já referido Francisco Alves e Lourenço d'Almeida Azevedo (1833-91), esta obra veio responder aos apelos de combinação dos esforços empreendidos por médicos e químicos no estudo das águas minerais. Foi considerada "a primeira obra methodica, regular e perfeita, que deste género se há publicado em Portugal nos tempos modernos", ${ }^{40}$ opondo-se "como paradigma de mérito distincto" aos relatórios de Lourenço sobre as águas de Vidago. Na bibliografia publicada n' O Instituto, aludiu-se também à obra de Costa Simões sobre os Banhos do Luso como sendo similar na abrangência ao estudo realizado. Foi reiterada a necessidade de reproduzir este exemplo, "sendo Portugal o paiz da Europa, que, havendo respeito á sua pequena extensão, possue maior numero de aguas mineraes, principalmente das que se denominam thermaes". ${ }^{41}$

\section{AS ANÁLISES QUÍMICAS DE ÁGUAS MINERAIS DE SANTOS E SILVA}

Joaquim dos Santos e Silva (1842-1906) foi aluno de Bernhard Tollens (1841-1918), no curto período em que este famoso químico alemão esteve em Coimbra. Por seu intermédio viajou até à Alemanha, onde estudou entre 1871 e 1873 química prática com Friedrich Wöhler (1800-82) e Friedrich August Kekulé (1829-96), nas Universidades de Goettingen e Bonn, respectivamente. Regressou a Coimbra para dirigir os trabalhos do Laboratório Chimico e, a partir de 1875, iniciou um conjunto de estudo de águas minerais, alguns dos quais publicados n' $O$ Instituto.

O primeiro exemplo destes estudos incidiu na então recentemente descoberta fonte de águas férreas, após obras realizadas na estrada da Beira, perto de Coimbra, em agosto de 1875. Rapidamente começaram a ser atribuídas a estas águas efeitos no tratamento de problemas crónicos do estômago e da bexiga. Como os testes preliminares eram inconclusivos, Santos e Silva decidiu realizar um conjunto de ensaios químicos, que descreveu em pormenor "a fim de que, em todo o tempo, os homens competentes possam dar ao meu trabalho o seu devido valor". ${ }^{42}$ Com esta minúcia na apresentação pretendia diferenciar o seu trabalho de outros que não esclareciam quais eram os métodos empregados, de forma de ocultar a pouca confiança nos seus resultados. O trabalho foi dividido em três partes: propriedades físicas, análise química qualitativa e análise química quantitativa.

$\mathrm{O}$ estudo das propriedades físicas comportava o aspecto geral, cheiro e sabor, a temperatura a diferentes horas e a densidade. A análise qualitativa envolveu um conjunto de testes a amostras filtradas com base na adição de vários reagentes. Posteriormente, $24 \mathrm{~L}$ foram expostos ao ar durante 5 dias, tendo sido recolhido por filtração o respectivo depósito. Tanto o depósito como a água filtrada foram sujeitos a um novo conjunto de testes para determinar a presença dos princípios mineralizadores. A última e mais importante etapa foi a análise quantitativa do cloro, da sílica, do ácido sulfúrico, do ácido carbónico, do ácido fosfórico, do ferro, do manganês, do cálcio, do magnésio, dos metais alcalinos (de acordo com os resultados dos testes qualitativos) e do resíduo sólido. Baseado nos valores obtidos e nas afinidades químicas entre os elementos mineralizadores, Santos e Silva calculou os sais presentes. ${ }^{43}$ A diferença entre os valores so- 
mados e o valor efectivo do resíduo sólido foi atribuída à "influência da sílica sobre os carbonatos, durante a evaporação da água até à secura". ${ }^{44}$ Para finalizar, e após apresentar um quadro onde comparou os resultados obtidos na sua análise com os resultados de análises de outras águas carbonatadas férreas de Nassau, na Alemanha, efectuadas pelo químico alemão Carl Remigius Fresenius (1818-97), Santos e Silva deixou um conjunto de precauções na acomodação em frascos e transporte de forma a garantir a preservação das características destas águas minerais.

No ano seguinte, em 1876, a atenção de Santos e Silva centrouse nas águas termais das Caldas da Rainha, as mais conhecidas em Portugal. A primeira parte do estudo recaiu sobre todas as análises antes executadas, considerando que nenhum dos trabalhos publicados até 1793, em particular os realizados por Vandelli e pelos seus discípulos em Coimbra, tinha valor no que concerne à composição química. ${ }^{45}$ Contudo, Santos e Silva reconheceu valor científico ao estudo de Withering, realizado em 1793 e publicado dois anos depois, considerando ser "a primeira analyse d'aquellas aguas que apresenta um certo cunho da sciencia, e revela no seu auctor conhecimentos chimicos muito superiores aos que antes d'elle se occuparam do estudo das aguas das Caldas". ${ }^{46}$

Quanto às análises, Santos e Silva seguiu um protocolo similar ao que foi usado nas águas da estrada da Beira. A análise quantitativa das espécies químicas detectadas baseou-se, sobretudo, em métodos gravimétricos, apesar de, no caso do ácido sulfídrico (sulfuretos), terem sido empregados em paralelo um método volumétrico e um método gravimétrico. ${ }^{47,48}$ Uma vez mais, aquele químico calculou os sais presentes em solução na água mineral. Concluiu o seu estudo com uma análise comparativa dos seus resultados com os que tinham sido obtidos em análises anteriores, desde 1793 (Figura 2).

Surgiram algumas dúvidas sobre a conversão dos valores obtidos por Withering, dada a incerteza nas unidades de massa usadas. ${ }^{49}$ Santos e Silva indicou, também, os resultados das análises feitas a estas águas em 1849 e 1858 por Júlio Máximo de Oliveira Pimentel (1809-84) - 2. ${ }^{\circ}$ Visconde de Vila Maior, ${ }^{50}$ também sócio do IC e desde 1838 lente de Química na Escola Politécnica de Lisboa. Concluiu que, se as suas conjecturas sobre a conversão dos valores de Withering fossem correctas, os resultados das várias análises concordariam, dentro dos erros experimentais, tendo as águas das Caldas da Rainha mantido a sua composição química ao longo dos últimos 80 anos. ${ }^{51}$

Em 1879, num estudo das águas alcalino-gasosas das Fontes de Bem-Saúde, em Vila Flor, Bragança, cuja exploração foi relevante entre 1893 e 1911, Santos e Silva optou, novamente, por uma descrição minuciosa dos processos usados na determinação das quantidades dos sais presentes, como forma de permitir uma avaliação precisa de quem tinha competência no assunto e assim justificar o seu "modo de ver com relação ao agrupamento dos ácidos e das bases, que differe um pouco do modo de ver de alguns analystas, aliás de merecimento ${ }^{52}$ Este foi o primeiro estudo químico destas águas e, dada a sua natureza alcalino-gasosa, efectuou uma análise complementar dos gases libertados, que determinou uma percentagem de 97,36\% em volume de dióxido de carbono (ácido carbónico). Confrontando estes resultados com os de outras águas similares, concluiu que as águas de Bem-Saúde satisfaziam as indicações médicas atribuídas às demais, especificamente as das Pedras Salgadas, em Vila Pouca de Aguiar, e as de Vidago, perto das anteriores. ${ }^{53}$

Três anos volvidos, voltou a surgir nas páginas d'O Instituto um novo estudo de águas minerais da autoria de Santos e Silva, desta vez sobre uma água do Vidago recentemente descoberta. Este trabalho foi encomendado e financiado pelo proprietário da nascente, Augusto César de Morais Campilho (1825-1907). Segundo Santos e Silva, a água que brotava dessa nova nascente apresentava a mesma composição qualitativa e quantitativa das águas de Vidago, comercializadas

\section{Mlappa representativo da composição chimica das aguas thermaes das Caldas da Rainha, segundo as analyses feitas por:}

\begin{tabular}{|c|c|c|c|c|c|}
\hline \multirow[b]{3}{*}{$\begin{array}{l}\text { Temperatura..... } \\
\text { Densidade ........ }\end{array}$} & \multirow{2}{*}{$\begin{array}{l}\text { Withering } \\
\text { em } 1793\end{array}$} & \multicolumn{2}{|c|}{ J. M. de 0. Pimentel } & \multirow{2}{*}{$\begin{array}{l}\text { Lourenço } \\
\text { em } 1867\end{array}$} & \multirow{2}{*}{$\begin{array}{l}\text { Santos } \\
\text { em } 1876\end{array}$} \\
\hline & & em 1849 & em 1858 & & \\
\hline & $\begin{array}{c}33^{\circ}, 88 \mathrm{C} . \\
1,00225\left(^{(0)}\right.\end{array}$ & $\begin{array}{c}34^{\circ}, 5 \mathrm{C} . \\
1,00422\end{array}$ & $\begin{array}{c}33^{\circ}, 4 \mathrm{C} . \\
-\end{array}$ & $\begin{array}{l}33^{\circ}, 8 \mathrm{C} . \\
-\end{array}$ & $\begin{array}{l}34^{\circ}, 5 \mathrm{C} . \\
1,00267\end{array}$ \\
\hline 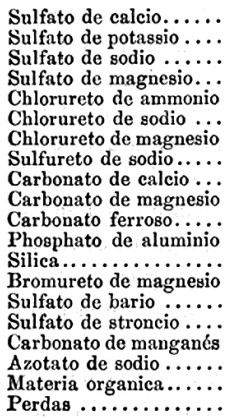 & $\begin{array}{c}0,71614 \\
\overline{1} \\
1,04166 \\
- \\
\overline{-} \\
1,40885 \\
1,04166 \\
\overline{-} \\
0,19530 \\
0,05760 \\
0,04690(1) \\
0,02034(3) \\
0,01227 \\
- \\
- \\
- \\
- \\
- \\
-\end{array}$ & $\begin{array}{c}0,4784 \\
- \\
\overline{-} \\
0,2487 \\
\overline{-} \\
1,4518 \\
0,0472 \\
0,0024 \\
0,1360 \\
-\overline{0} \\
0,0020\left(^{2}\right) \\
0,0100{ }^{(3)} \\
0,0150 \\
- \\
\overline{-} \\
\overline{-} \\
\overline{-} \\
0,0271 \\
0,0064\end{array}$ & $\begin{array}{c}0,4276 \\
- \\
0,1404 \\
0,2088 \\
\overline{1,5940} \\
-\overline{0} \\
0,0027 \\
-\end{array}$ & 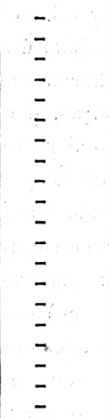 & $\begin{array}{c}0,73877 \\
0,04023 \\
0,25046 \\
- \\
0,00285 \\
\mathbf{1}, 72048 \\
0,17952 \\
- \\
0,19607 \\
0,05911 \\
0,00195 \\
0,00338 \\
0,01973\end{array}$ \\
\hline Somma das subst. fixas & 5,54072 & 2,4250 & 2,6277 & 2,7850 & $\left(\mathrm{v} . \circ \mathrm{n} .^{\circ} 13\right)$ \\
\hline $\begin{array}{l}\text { Acido carbonico para } \\
\text { formar os bicarbon.os } \\
\text { Acido carbonico livre... } \\
\text { Acido sulf hydrico livre } \\
\text { Azote................. }\end{array}$ & $\begin{array}{l}- \\
\overline{-}\end{array}$ & $\begin{array}{c}0,0590 \\
? \\
0,00486 \\
?\end{array}$ & $\begin{array}{c}0,0919 \\
? \\
? \\
?\end{array}$ & $\begin{array}{c}- \\
0,0085 \\
-\end{array}$ & $\begin{array}{l}0,11797 \\
0,14050 \\
0,00998 \\
0,02488\end{array}$ \\
\hline $\begin{array}{r}\text { Somma das subst. fixas } \\
\text { e volateis ............. }\end{array}$ & - & - & - & - & 3,50588 \\
\hline vol. dos $\left\{\begin{array}{l}\text { Oxygenio ......... } \\
\text { Azote.......... } \\
\text { Acido sulf hyd. } \\
\text { Acido carbonico }\end{array}\right.$ & $\begin{array}{l}- \\
\overline{-}\end{array}$ & $\begin{array}{r}1^{\mathrm{cc} \cdot}, 398 \\
21^{\mathrm{cc} \cdot}, 679 \\
3^{\mathrm{cc} \cdot}, 148 \\
35^{\text {ce. }}, 325\end{array}$ & $\begin{array}{r}1^{\text {ce. }}, 08 \\
16^{\text {ce. }}, 70 \\
4^{\text {ce. }}, 75 \\
61^{\text {ce. }}, 20\end{array}$ & $\begin{array}{l}- \\
- \\
-\end{array}$ & $\begin{array}{r}22^{c e \cdot}, \overline{25} \\
7{ }^{c c \cdot}, 39 \\
80^{c c \cdot}, 46\end{array}$ \\
\hline
\end{tabular}

(1) O auctor considera esta densidade como uma simples aproximagão. (1) Sulfureto de ferro.

(3) Alumina pura.

Figura 2. Mapa comparativo das diversas análises realizadas às águas termais da Caldas da Rainha ${ }^{51}$

em garrafas, confirmando a sua asserção pela comparação com as análises publicadas pela empresa distribuidora em $1879 .{ }^{54}$ Neste estudo, além das análises efectuadas por Santos e Silva, foi incluída uma monografia do médico e professor universitário Raimundo da Silva Motta (1840-1910) sobre os efeitos terapêuticos das águas. Este médico iniciou a sua exposição sublinhando a importância dos estudos hidrológicos das águas minerais nacionais como garantia do seu valor terapêutico, assegurando o seu valor por comparação com águas estrangeiras que eram vendidas nas farmácias e cuja composição era bem conhecida. Não obstante, defendeu os ensaios médicos dos efeitos clínicos das águas por entender insuficientes as conclusões que se poderiam retirar da composição química, não se devendo "considerar as aguas mineraes como formulas compostas (...) é indispensável conhecer pela experiência e observação prolongada os effeitos que elas são capazes de produzir, quer no estado physiologico, quer em diversos estados pathologicos". ${ }^{5}$ Silva Motta dizia que era preferível o tratamento na origem, no respectivo estabelecimento balnear, aproveitando as comodidades e distracções proporcionadas. Apesar de admitir que os efeitos fisiológicos das águas em análise eram insignificantes ou nulos, descreveu um conjunto de situações em que achava apropriada a sua aplicação, quer por ingestão, quer em banhos. Embora não sejam descritos em pormenor, mencionou alguns ensaios clínicos realizados no Hospital da Universidade de Coimbra e numa clínica particular com garrafas de água, devidamente acondicionadas, provenientes da fonte Campilho. Os efeitos observados eram similares aos obtidos com outras águas da região.

Este último estudo das águas Campilho mostrou não só a necessidade de legitimação científica por parte dos proprietários e empresas 
distribuidoras, mas também a perversidade que resulta do facto de ser o proprietário a encomendar e financiar o trabalho. Santos e Silva, mantendo o rigor científico, sancionou a qualidade desta nova água mineral, por comparação com as restantes águas da marca Vidago, aproveitando para alertar o governo e os cidadãos a respeito da não indicação da composição química nos rótulos das garrafas comercializadas. No discurso de Silva Motta é, contudo, flagrante a vontade de publicitar as virtudes das águas da nova nascente, mais por tentativa de agradar a quem comissionou o estudo do que por existirem resultados evidentes e objectivos, o que não foi o caso na parte a cargo de Santos e Silva. O trabalho deste último fornecia toda a informação que permitisse a outros avaliar o real valor do seu contributo, inclusivamente a quem não concordasse com alguns dos métodos.

Ao longo da segunda metade do século XIX, outros químicos e médicos realizaram análises de águas minerais, um tema tratado pelo escritor Ramalho Ortigão (1836-1915) que, em 1875, publicou o livro Banhos de Caldas é Águas Minerais. No entanto, a falta de legislação fazia-se sentir na hidrologia portuguesa e na forma como eram realizadas as análises químicas, não ficando totalmente claro o grau da influência do proprietário que as encomendava sobre o analista que as levava a cabo.

\section{A REGULAMENTAÇÃO DAS ÁGUAS MINERAIS PORTUGUESAS}

Por decreto de 30 de setembro de 1892, toda a exploração comercial das nascentes de águas minero-medicinais em Portugal foi finalmente regulamentada. Os proprietários ficaram obrigados à apresentação de requerimento e sujeitos a inspecção por parte da Junta Consultiva de Saúde Pública. ${ }^{56}$ Este decreto alterou profundamente o negócio das águas minerais, desencadeando uma grande procura das análises químicas. Os nomes que inspiravam maior segurança eram também aqueles com maior experiência e reputação, como Lourenço e Santos e Silva. Neste ano foram numerosos os estudos publicados, sendo incontornável a obra de Alfredo Luís Lopes (1853-1937) sob o título Águas minero-medicinais de Portugal, onde, para além dos dois capítulos iniciais onde descreveu as características das águas minero-medicinais e o respectivo tratamento hidrotermal, elencou as principais águas portugueses com as respectivas propriedades físicas e químicas e indicações terapêuticas. ${ }^{57}$

Um novo estudo químico de águas surgiu nas páginas d' O Instituto em 1896, desta vez da autoria de António Joaquim Ferreira da Silva (1853-1923), professor de Química no Porto, fundador e director do Laboratório Químico Municipal dessa cidade, onde realizou as análises das águas minerais e potáveis de Moledo. Tratou-se de uma reedição de uma memória publicada antes, mas foram incluídos "documentos analyticos e alguns desenvolvimentos que possam interessar ás pessoas da especialidade ${ }^{58}$ Ferreira da Silva organizou o seu estudo de forma diversa da de Santos e Silva, dedicando a primeira parte do seu trabalho à termalidade, sulfuração, alcalinidade e composição química das águas das várias nascentes de Moledo. A termalidade correspondia ao estudo comparativo das temperaturas das águas das nascentes a várias horas do dia, verificando Ferreira da Silva que a sua temperatura média coincidia com a temperatura humana, sendo por isso muito favorável o seu uso balnear. ${ }^{59}$ A sulfuração correspondia à determinação do enxofre, e respectivos compostos (sulfuretos, sulfatos, etc). A descrição das análises realizadas é mais resumida, limitando-se ao método usado e etapas principais. Ferreira da Silva também realizou uma série de ensaios e observações das águas das fontes, registando algumas características físicas das águas e procedendo desde 1892 a testes químicos qualitativos. A alcalinidade das águas era determinada quer pelo papel de tornesol quer por métodos volumétricos, como a adição de uma solução de ácido sulfúrico, usando a fenolftaleína como indicador. A alcalinidade estaria associada ao teor de "sulfhidratos, carbonatos e silicatos que a água contém”, sendo expressa em quantidades de ácido sulfúrico ou carbonato de sódio. ${ }^{60}$ Os métodos quantitativos da análise química eram idênticos aos realizados por Santos e Silva, apresentando Ferreira da Silva os seus resultados sob a forma de uma "composição elementar das águas” onde figuravam os metais presentes, os ácidos representados pelos seus "resíduos halogénicos" $\left(\mathrm{SO}^{4}\right.$ ou $\left.\mathrm{CO}^{3}\right)$, os halogéneos, a sílica, o amoníaco, entre outros. ${ }^{61}$ Posteriormente, Ferreira da Silva procedeu ao que designou por "agrupamento hipotético dos elementos das águas sulfúreas de Moledo”, calculando os sais presentes em solução. ${ }^{62} \mathrm{Na}$ comparação com análises anteriores, destacou o facto de que o estudo da alcalinidade ser pioneiro e a detecção de nitratos e de sulfato de amónio não terem sido detectados noutras águas do reino. $\mathrm{O}$ estudo contém também uma análise comparativa com as restantes águas sulfúreas nacionais e internacionais e termina com uma análise da potabilidade das águas de Moledo sob o ponto de vista químico e médico.

O trabalho de Ferreira da Silva foi muito influenciado pelos tratados de análise química do alemão Carl Fresenius, o primeiro, de 1841, dedicado à análise qualitativa, e o segundo, saído cinco anos depois, sobre a análise quantitativa. A admiração manifestada por Ferreira da Silva por Fresenius pode ser verificada no artigo laudatório por ocasião da morte do alemão, que publicou n' $O$ Instituto, ${ }^{63}$ onde resumiu os novos métodos desenvolvidos por aquele químico, que efectuou mais de cinco dezenas de análises químicas de águas minerais da Alemanha, Áustria e Hungria.

Uma última memória n' $O$ Instituto dedicada ao estudo de águas minerais, também da autoria de Ferreira da Silva, incidiu sobre as águas de Caldas de Canaveses. Ferreira da Silva já tinha realizado um primeiro reconhecimento analítico destas águas, a pedido do proprietário, pelo que se subentende que este estudo mais extenso tenha sido encomendado também por ele. No primeiro capítulo explicou as características geológicas e geográficas, sendo mesmo dadas informações turísticas, como a estação de caminho de ferro mais próxima, e a descrição das pontes sobre o Tâmega. A tentativa de promoção da estância termal é flagrante, apesar de se tratar de um trabalho científico. As partes seguintes seguem a estrutura habitual das análises químicas de águas, começando com a análise qualitativa que continha uma descrição sumaríssima do resultado para cada espécie química testada. O estudo prosseguiu com a análise quantitativa, indicando o método e os valores aferidos para os vários componentes minerais presentes. Terminava com a apresentação dos resultados finais em dois quadros: um baseado no sistema adoptado por químicos ingleses e franceses onde figuram os metais e os resíduos halogénicos dos ácidos, e outro onde foram apresentados os metais como óxidos básicos (cal, magnésia, potassa, soda óxido de ferro, etc) e os ácidos como anidridos, forma usual adoptada por Fresenius e outros analistas portugueses. ${ }^{64}$ Para estabelecer a composição da água mineral com base em sais, Ferreira da Silva calculou a análise e terminou classificando as águas minerais de Canaveses em "mesothermais, hyposalinas, sulfureas-sodicas, alcalinas, lithinadas e arseniacaes", ${ }^{65}$

\section{A ANÁliSE DAS ÁGUAS PARA ABASTECIMENTO PÚBLICO}

Apesar das preocupações com a qualidade da água destinada ao consumo humano se terem feito sempre sentir, revelou-se escasso o controlo que as populações tinham sobre este aspecto das suas vidas, excepto talvez no sentido de evitar degradar algumas fontes com excrementos ou outros efluentes provenientes da actividade humana. Com a Revolução Industrial e com o aumento de fontes de poluição, este assunto tornou-se de importância capital para a sustentabilidade das grandes cidades europeias. ${ }^{66}$ 
Foi no século XIX que as políticas de higiene pública se implantaram, com o objectivo de evitar não só problemas relacionados com envenenamentos mas também a transmissão de doenças e a ocorrência de epidemias atribuídas, pelo menos em parte, ao abastecimento público de águas. Em 1859, os químicos Hofmann e Edward Frankland (1825-99) foram chamados para "desodorizar" os esgotos de Londres na tentativa de melhorar o cheiro nauseabundo do rio Tamisa. Esta situação conduziu à criação de uma Comissão Real para a Poluição de Rios e, cerca de 10 anos depois, Frankland chefiava um laboratório dedicado à investigação da poluição de rios. Nos anos que se seguiram, este químico tornou-se uma referência mundial neste tema, desenvolvendo novos métodos e técnicas de análise de águas, e um dos maiores activistas da qualidade da água fornecida às populações. ${ }^{67}$

Em Portugal, este problema foi desde logo suscitado por Costa Simões, na cidade de Coimbra. Em 1868 foi criada a Companhia de Águas de Lisboa. Foi, contudo, preciso esperar pelas últimas décadas do século XIX para os assuntos relativos à qualidade da água se imporem nos círculos académicos portugueses e ser dada uma maior atenção às respectivas análises químicas.

A importância dada a este assunto pelos sócios do IC foi confirmada pelas conferências realizadas no salão nobre desta sociedade em 1879 por José Epifânio Marques (1831-1908), médico natural de Estremoz, doutorado em 1861 em Coimbra, e autor de vários artigos n'O Instituto.

A primeira conferência, de 3 de Maio, teve por título Valor Hygienico da Agua Potavel. Marques iniciou a sua prelecção explicando o conceito de agente modificador, presente em todos os materiais com que contactamos diariamente, desde o ar, o vestuário e os alimentos e bebidas, definindo-o como "agentes naturaes ou accidentaes, physicos ou dynamicos, susceptiveis de fazer variar as condiçoes de vida do homem individual ou collectivo". ${ }^{68}$ Falou depois sobre o caso da água e da sua ingestão pelo homem, realçando as suas virtudes fisiológicas. Referiu os efeitos inerentes à sua temperatura e debruçou-se na importância da sua "pureza hygienica". Desta forma, a água fluvial, fruto do arraste de "numerosos corpúsculos e impurezas", não possuía a pureza da "destillada em nossos laboratórios”, considerando-se potável aquela que se apresentava límpida e temperada, de sabor agradável e privada de substâncias orgânicas. Marques advertiu que, mesmo a água cristalina e inodora não é pura, podendo conter "princípios nocivos, como sulfato de cal e matéria orgânica não decomposta”, uma vez que "a pureza hygienica da água não se mede pela sua pureza chimica, devendo pelo contrario a água potável conter princípios alheios á sua composição atómica" ${ }^{69}$ Considerou que a existência de gases dissolvidos era uma condição da potabilidade da água, nomeadamente o ar e o "ácido carbónico", remetendo depois a discussão para os sais terrosos. Explicou o método simples de verificar a dureza da água com recurso à espuma produzida por adição de sabão, descrevendo o processo de Boutron e Boudet, estabelecendo como imprópria a água cujo grau hidrotimétrico excedesse os $20^{\circ}$, referindo os seus efeitos no uso doméstico e as suas características incrustantes. Indicou um conjunto de exemplos para serem adoptados para melhorar a potabilidade da água, quer ao nível das águas de abastecimento quer a nível quotidiano, pelas populações, como por exemplo a construção de filtros. Por último, abordou alguns processos químicos de análise e tratamento e referiu a presença de "animaes e vegetaes infinitamente pequenos", visíveis ao microscópio que eram "fonte de putrefacção para a água, e uma origem de perigos para os que a bebem", um problema que poderia ser corrigido pela fervedura e adição de algumas gotas de álcool, vinagre ou ácido sulfúrico. ${ }^{70}$

A segunda conferência de Marques ocorreu em 24 de maio. Nela foi defendida a tese que "a insalubridade das povoações em geral, $e$ a de Coimbra em particular, estão em grande parte subordinadas á falta d'agua potavel, e sobretudo á sua má distribuição". ${ }^{71} \mathrm{O}$ orador começou por descrever alguns marcos na história do abastecimento público de água no mundo e em Portugal, dando o exemplo das preocupações higiénicas em Inglaterra. $\mathrm{O}$ orador falou sobre os perigos e consequências do consumo de águas impróprias, por razões químicas e/ou biológicas, alertando para os problemas específicos das águas de Coimbra e apontando algumas soluções a adoptar pela Empresa de Águas de Coimbra, representada na altura por Costa Simões e por Adolfo Ferreira Loureiro (1836-1911), o autor do projecto que seria publicado no volume seguinte d' $O$ Instituto. ${ }^{72}$ Marques foi presidente do IC de 1893 a 1896.

Entre 25 de junho e 16 de julho de 1894, Ferreira da Silva realizou um conjunto de conferências na Sociedade União Médica do Porto sobre o exame das águas potáveis, sob o ponto de vista da higiene, que também foram publicadas n' $O$ Instituto. Em 1881, Ferreira da Silva tinha publicado os seus primeiros trabalhos sobre análise de águas, designadamente Aguas, teorias chimicas e As aguas do Rio Souza e os mananciaes e fontes da cidade do Porto, que serviu de base ao projecto de abastecimento público de água nesta cidade. ${ }^{73}$ Nessas conferências, o autor estabeleceu quatro componentes da análise de águas: o exame físico e organoléptico, o exame químico, o exame microscópico e o exame bacteriológico. ${ }^{74} \mathrm{Na}$ sua memória descreveu pormenorizadamente os métodos, técnicas e instrumentos a usar. Estabeleceu as condições de potabilidade de uma água, definindo para cada componente os parâmetros que permitiam classificar a água em: água muito pura, água potável, água suspeita e água má. A memória incluiu figuras representando muitos dos aparelhos e esquemas de montagem usados e as respectivas equações químicas que acompanhavam cada teste (Figuras 3 e 4). ${ }^{75} \mathrm{O}$ autor dissertou, também, sobre o exame microscópico, considerando que uma água salubre não deveria conter micro-organismos em quantidade apreciável. Na última conferência, de 16 de julho, abordou as análises realizadas às águas de poços do Porto cuja memória continha uma carta hidrográfica e de relevo do Porto. ${ }^{76}$
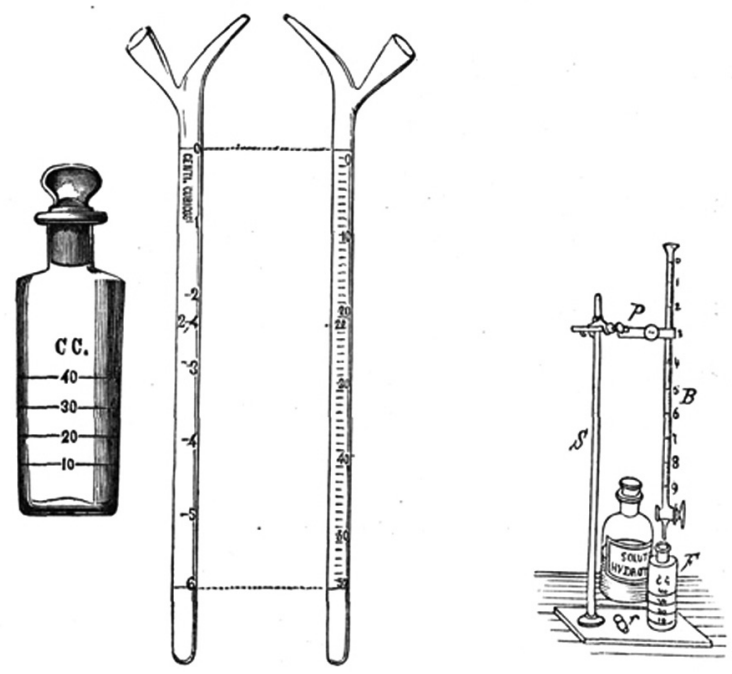

Figura 3. Material usado na determinação dos graus hidrotimétricos ${ }^{74}$

Após as pioneiras análises feitas por Alves às águas de Coimbra, em 1862, decorreram 35 anos sem haver quaisquer exames químicos, muito embora tivesse sido concretizado o projecto de abastecimento público, com obras iniciadas em 1882. O francês Charles Lepierre (1867-1945), na altura chefe de trabalhos do Gabinete de Microbiologia da Faculdade de Medicina da UC, assumiu esta tarefa e, em conjunto com o professor de Farmacotecnia na Escola de Farmácia da UC, Vicente José de Seiça (1858-1928), analisou 25 amostras de 


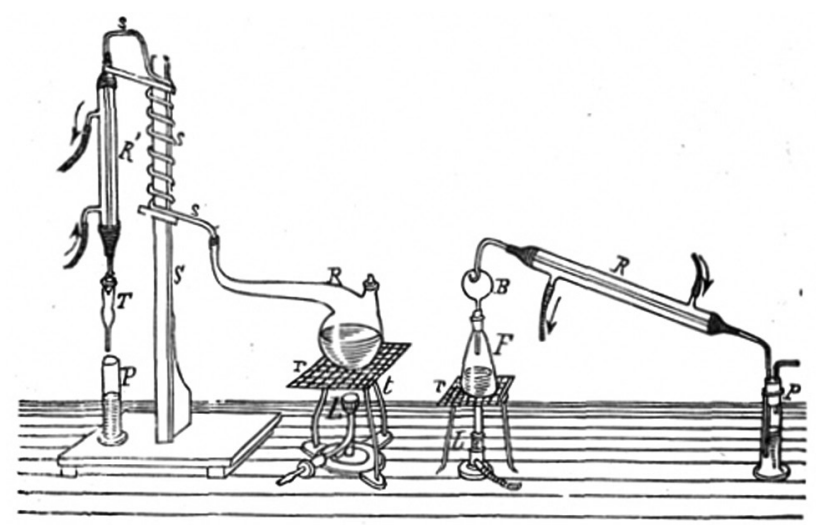

Figura 4. Aparelhos de destilação usados na determinação do amoníaco ${ }^{74}$

águas de fontes e poços da cidade, da água do Mondego e da água canalizada no laboratório da Escola Industrial Avelar Brotero.

Lepierre tinha concluído o curso de engenharia química na Escola de Física e Química Industriais de Paris em 1887. Foi aluno de Roberto Duarte Silva (1837-89), um químico português de origem cabo-verdiana que foi nomeado professor da referida escola em 1881 e eleito seis anos depois presidente da Sociedade de Química de Paris. Por influência de Duarte Silva, Lepierre veio para Portugal em 1888, passando a dirigir os trabalhos práticos de química da Escola Politécnica de Lisboa. No ano seguinte, foi nomeado professor da Escola Industrial Brotero, em Coimbra, ingressando depois no Gabinete de Microbiologia da Faculdade de Medicina da UC. Durante os 20 anos em que esteve em Coimbra, desempenhou várias funções, incluindo a direcção dos Serviços Municipalizados, tendo criado um curso livre de Química Biológica, no ano lectivo de 1897-98, que funcionou no IC. ${ }^{77}$ Seiça, farmacêutico e Professor de Farmacotecnia na Escola de Farmácia de Coimbra, foi director do Dispensatório Farmacêutico da UC. Ambos foram sócios do IC.

Lepierre participou no 2. ${ }^{\circ}$ Congresso Internacional de Química Analítica, realizado em Paris em 1896, tendo sobre ele publicado um extenso relatório n' $O$ Instituto. Nesse escrito começou por considerar o século XIX o século dos congressos, declarando-se partidário deles como momentos propícios ao esquecimento de rivalidades científicas e à criação de meios directos ou indirectos com o fim de contribuir para a felicidade humana. ${ }^{78}$ Organizou, em conjunto com Ferreira da Silva, a comissão portuguesa mas, dada a impossibilidade por razões de saúde deste último se deslocar, Lepierre foi o único representante de Portugal no congresso. Embora tenha tentado que houvesse uma participação mais alargada de trabalhos nacionais, apenas dois trabalhos viriam a ser apresentados no congresso, um da autoria de Ferreira da Silva sobre os vinhos da Madeira e outro de Lepierre sobre a dosagem de ácido fosfórico nas águas potáveis. ${ }^{79}$ A escassez de artigos portugueses foi justificada "pela estreiteza do tempo, ou por ser assumpto novo entre nós, os nossos collegas não conseguiram vencer o receio de publicar, que geralmente se nota no homem de sciencia português" ${ }^{80}$ A participação de Lepierre neste congresso terá estimulado a sua vontade de pôr em prática os novos métodos da química analítica no estudo das águas, em consonância com as crescentes preocupações manifestadas na Secção IX (Química aplicada à medicina, à farmácia, à higiene e à alimentação), na qual Lepierre tomou parte mais efectiva. ${ }^{81}$

Embora o estudo das águas de Coimbra pretendesse incluir análises bacteriológicas e microscópicas, apenas foram publicadas n' $O$ Instituto as análises químicas, num trabalho que foi oferecido à cidade e apresentado na Câmara Municipal, sendo realizado no "pouco tempo que nos fica disponível dos nossos trabalhos officiaes reconhecido hoje como de primeira necessidade". ${ }^{22}$ Os métodos adoptados por Lepierre e Seiça eram idênticos aos apresentados nas conferências de Ferreira da Silva três anos antes, com excepções de alguns pormenores realçados na descrição. Um exemplo é o método de Boutron-Boudet para determinar a dureza das águas, o também chamado método hidrotimétrico que ainda hoje é usado e que já tinha sido adoptado por Alves. Lepierre considerava o método imperfeito, pelo que propôs algumas alterações que tinha defendido numa proposta de unificação dos métodos das análises químicas e bacteriológicas das águas, apresentada no $2 .^{\circ}$ Congresso Internacional de Química Aplicada de Paris, em 1896. Também os valores paramétricos usados para classificar as águas em puras, potáveis, suspeitas ou más eram, basicamente, os mesmos que os de Ferreira da Silva. Um argumento na qualificação de uma água potável era que esta não poderia conter componentes que não existissem no organismo humano, uma vez que o estado da ciência de então não era capaz de explicar a acção fisiológica de muitas espécies químicas. ${ }^{83}$ Lepierre e Seiça terminaram o seu trabalho com um conjunto de quadros comparativos das diversas águas para cada espécie química analisada e um quadro geral onde se apresentam todos os resultados. As águas canalizada e do Mondego foram consideradas puras. Das restantes, apenas uma era potável enquanto muitas foram qualificadas como péssimas. ${ }^{84}$ No trabalho de Lepierre e Seiça já não se efectuou o tradicional cálculo da análise, o que demonstra ter-se tornado desnecessário este procedimento ou ser ele apenas reservado às águas minerais. Nas conclusões são referidos alguns estudos microscópicos da água canalizada, que conteria entre 300 a 400 micróbios por grama, um valor dentro da escala das águas puras e muito inferior ao verificado nas águas do rio Mondego, que não eram filtradas.

As análises microbiológicas das águas de Coimbra foram realizadas em 1902, ${ }^{85}$ no recente Laboratório de Microbiologia e Química Biológica, que mais não era do que uma reestruturação fomentada por Lepierre do Gabinete de Microbiologia. Após estes primeiros trabalhos, toda a carreira de Lepierre esteve intimamente ligada ao tema da hidrologia médica e, em particular, às análises de águas, tornando-se um analista muito requisitado, uma vez que o seu nome servia os propósitos publicitários. Ao longo das décadas seguintes, Lepierre realizou dezenas de análises de águas minerais portuguesas, tendo sido pioneiro na aplicação de novos métodos de análise. Desenvolveu também trabalhos no âmbito da condutibilidade eléctrica e da radioactividade das águas. ${ }^{86}$

\section{CONSIDERAÇÕES FINAIS}

A perspectiva histórica da evolução da análise química das águas para consumo humano revela o crescente impacte desta área científica ao longo do século XIX. Portugal não foi excepção neste domínio, tendo havido consciencialização do valor económico das águas minerais. A riqueza de fontes naturais de águas minerais no país levou à realização de vários estudos científicos, aplicando os mais recentes métodos, que serviram sempre para legitimar o valor das águas. O primeiro exemplo foi o das águas das Caldas da Rainha, cuja fama internacional desde logo atraiu o interesse de investigadores estrangeiros, como foi o caso de Withering no século XVIII, a que se seguiram sucessivos estudos de investigadores portugueses ao longo do século XIX.

As análises realizadas pela Sociedade Farmacêutica Lusitana a várias águas minerais, em 1838, por deliberação do governo, marcaram o início de uma aplicação sistemática dos novos métodos de análise química, a fim de aproveitar um recurso tão importante num país que sempre teve dificuldades económicas e escassez de recursos naturais. No entanto, esta iniciativa não teve continuação nos anos seguintes. 
Seguindo o exemplo das Caldas da Rainha, Costa Simões anteviu idênticas possibilidades de sucesso para as águas do Luso e criou as bases deste projecto com uma abordagem científica que veio a ser emulada noutras fontes de águas minerais. Rapidamente se estabeleceu como factor de legitimação de qualquer empreendimento termal a realização de análises químicas do produto que se pretendia comercializar, apesar de ainda serem desconhecidos os nexos causais entre os componentes minerais detectados e a sua acção fisiológica. Os estudos químicos seriam complementados por ensaios clínicos dos efeitos terapêuticos. Desta forma foi florescendo a nova disciplina da hidrologia médica. Se o móbil que desencadeou os estudos das águas minerais foi o económico, já no que concerne às águas de abastecimento público o agente foi a preocupação com questões de higiene pública que se intensificaram a partir da segunda metade do século XIX.

Alves deu continuidade a Costa Simões, quer no que respeita às análises das águas do Luso quer relativamente às águas de abastecimento de Coimbra. Em simultâneo, novas deliberações governamentais, em 1860 e 1866, e o trabalho de Lourenço permitiram o avanço do estudo das águas minerais, suscitando um novo interesse sobre este tema e a internacionalização na Exposição Internacional de Paris de 1867. As conferências de Marques, realizadas no IC em 1879, revelaram as crescentes preocupações sobre a qualidade das águas de abastecimento público e tiveram impacto no projecto realizado em Coimbra nos anos seguintes. Também os trabalhos de Santos e Silva podem ser considerados precursores, não só porque antecederam o decreto de 1892, mas também pelo rigor científico com que foram levados a cabo e pela preocupação com a descrição pormenorizada dos métodos.

No ano de 1892 iniciou-se um novo ciclo no tocante às águas minerais portuguesas. $\mathrm{O}$ governo acabou por regulamentar toda esta actividade, o que levou os agentes que comercializavam este produto a solicitar novas análises químicas, preferindo os analistas mais conceituados. O nome do autor da análise tornou-se uma garantia das virtudes publicitadas, autenticando o valor de uma água mineral. Três nomes se destacaram no número de análises e na fama científica que granjearam: Santos e Silva, Ferreira da Silva e Lepierre. Após a fundação do Gabinete de Química da Faculdade de Medicina da UC, seguiu-se, no final do século XIX, a criação de estabelecimentos dedicados às análises químicas de águas, de alimentos (bromatologia), médico-legais (toxicologia), de medicamentos, etc, de que são exemplos o Laboratório Químico Municipal do Porto, o Gabinete de Microbiologia da UC e o Instituto Bacteriológico Câmara Pestana de Lisboa. ${ }^{87}$ Todavia, só em 1910 foi criado o Instituto de Hidrologia de Lisboa e só em 1930 surgiram os seus congéneres do Porto e Coimbra, que tinham por fim principal a divulgação das qualidades terapêuticas das águas minerais e das respectivas estâncias. ${ }^{88}$

No século XX, a hidrologia continuou em desenvolvimento, embora o papel d' $O$ Instituto no tratamento dessa área passasse a ser menor. Outros estudos foram sendo publicados noutros lados. Luiz de Meneses Acciaiuoli (1888-1958), engenheiro chefe da Direcção Geral de Minas e Serviços Geológicos e inspector de águas, na sua História da Química na Hidrologia Portuguesa, concluiu que dos estudos referentes "às cento e algumas nascentes de águas minerais de Portugal" realizados até 1949 , cerca de $27 \%$ reportaram apenas indicações genéricas, $17 \%$ abordaram a matéria médica hidrológica e $16 \%$ incidiram em estudos químicos, físico-químicos e de radioactividade, o que demonstra a importância dada a estas análises. ${ }^{89}$ No entanto, ainda era defendido pelos médicos que as virtudes terapêuticas de uma água minero-medicinal eram definidas pela observação clínica dos seus efeitos, tendo a virtude da maior parte destas águas sido assinaladas pelo empirismo de muitos séculos. ${ }^{90}$ A Química ainda não tinha o devido papel. Actualmente, a Química ganhou alguma primazia relativamente à medicina: conhece-se bem a constituição das águas, mas reconhece-se que o mecanismo de actuação de muitos constituintes das águas minerais no organismo humano ainda é pouco conhecido. ${ }^{91}$

Com excepção de Lourenço e de Alves Ferreira, todos os químicos e médicos portugueses da segunda metade do século XIX aqui referidos foram personalidades associadas ao IC. Muitos deles tiveram uma actividade muito importante no seio desta academia. Assim, bastou a análise das suas memórias publicadas n' $O$ Instituto para traçar a sucessão dos eventos principais que marcaram a evolução da hidrologia em Portugal.

\section{AGRADECIMENTOS}

O primeiro autor agradece à Fundação para a Ciência e Tecnologia da qual é bolseiro de Doutoramento. Os autores agradecem ainda ao Dr. S. Formosinho, professor do Departamento de Química da Universidade de Coimbra, a leitura que fez do manuscrito.

\section{REFERÊNCIAS E NOTAS}

1. Coley, N. G.; Medical History 1990, 10, 56.

2. Ibid., p. 57.

3. Alfonso-Goldfarb, A. M.; Quim. Nova. 1996, 17, 203.

4. Hamlin, C.; A Science of Impurity. Water Analysis in Nineteenth Century Britain, University of California Press: Berkeley, 1990, http://ark.cdlib. org/ark:/13030/ ft667nb43t/, acessada em Março 2011.

5. Ihde, A. J.; The development of Modern Chemistry, Dover Publications, Inc: New York, 1984.

6. Ref. 4, p. 24.

7. Brock, W. H.; The Chemical Tree, W. W. Norton \& Company, Inc: London, 1992, p. 355.

8. Ref. 4, p. 30.

9. Ibid., p. 35-36.

10. Ibid., p. 48.

11. Acciaiuoli, L. M.; História da Química na Hidrologia Portuguesa, Academia das Ciências de Lisboa, 1949.

12. Acciaiuoli, L.; Águas de Portugal. Minerais e de Mesa. História e Bibliografia, Ministério da Economia, Direcção Geral de Minas e Serviços Geológicos, vol. II, 1944, p. 65-75.

13. Vandelli, D.; Análise da água dos banhos do Estoril, com notícias históricas pelo cirurgião Jacinto da Costa, 1778; Pessoa, J. M. da C.; Análise das Águas Termais das Caldas da Rainha, 1778; Gago, J. N.; Tratado Físico-Químico das águas das Caldas da Rainha, 1779.

14. Ferraz, M. H. M.; Medicamento Hist. Socied. 1996, 8, 1.

15. Carvalho, T. de; Azevedo, J. B. S.; Corvo, J. de A.; Lourenço, A. V.; Trabalhos preparatórios acerca das Águas Minerais do Reino. Imprensa Nacional: Lisboa, 1867.

16. Redinha, J. S.; Leitão, M. L. P.; Controlo químico da qualidade das águas minerais, Departamento de Química da UC: Coimbra, 1992, p. 12. Um destes críticos foi o naturalista alemão Johann Heinrich Friedrich Link (1767-1851) que percorreu Portugal numa viagem científica entre 1798 e 1799.

17. Guimarães, F.; Guimarães, J. L.; Hidrologia médica. Águas minerais de Portugal, Atlântida: Coimbra, 1954.

18. Withering, G.; Análise química das águas das Caldas da Rainha, 1795.

19. Ref. 15, p. 11.

20. Leonardo, A. J. F.; Martins, D. R.; Fiolhais, C.; Rev. Bras. Hist. Ciência 2009, 2, 192.

21. Leonardo, A. J. F.; Martins, D. R.; Fiolhais, C. Em Tesouros da Biblioteca Geral da Universidade de Coimbra; Amaral, A. E. M., ed.; Imprensa da Universidade: Coimbra, 2009, p. 115-125.

22. São vários os artigos que Costa Simões dedica às águas do Luso em 
O Instituto, incluindo dados sobre os regulamentos das termas e a sua administração assim como relatórios da Sociedade dos Banhos de Luso.

23. Simões, A. A. da C.; O Instituto 1852, 1, 5, 16, 29, 43, 52, 60, 72, 80.

24. Ibid., p. 7.

25. Jordão, A. M. D.; Considérations sur un cas de diabète, Adrien Delahaye, Librarie: Paris, 1857, p. 81. As águas analisadas foram das fontes da Cabeça, de Mira-Nova e Azevedo, em Monchique, da Venda Seca e Vale de Camarões, perto de Lisboa, e do Casal de Borras, perto de Mafra.

26. Alves, F. A.; O Instituto 1861, 10, 126.

27. Alves, F. A.; O Instituto 1862, 10, 231; 11, 29, 177.

28. Ibid., p. 231.

29. O método aplicado por Alves na determinação da dureza da água foi introduzido em França, em 1854, pelos químicos franceses Antoine Boutron e Félix Boudet, membros do Conselho de Higiene do departamento do Sena, na comparação de amostras de água. Baseava-se na adição de uma solução de sabão à amostra de água até a formação de uma espuma permanente, sendo que a quantidade de sabão necessária era proporcional à dureza da água. Um grau hidrotimétrico francês correspondia à adição de $100 \mathrm{~g}$ de sabão até obter uma espuma persistente, ou seja à presença na água de $10 \mathrm{mg} / \mathrm{L}(10 \mathrm{ppm}) \mathrm{de}$ carbonato de cálcio. Outras unidades usadas eram o grau inglês (um grão de carbonato de cálcio por galão) e o grau alemão (baseado na quantidade de óxido de cálcio).

30. Alves, F. A.; O Instituto 1872, 15, 198.

31. Este projecto seria assolado por inúmeras dificuldades relatadas em Simões (1890), demorando 17 anos até que os trabalhos de construção fossem iniciados (em 1882), com base no projecto de Loureiro publicado n'O Instituto - Loureiro, A. F.; O Instituto 1879, 27, 203.

32. Médico e higienista francês, professor na Faculdade de Medicina de Paris.

33. Simões, A. A. da C.; O Instituto 1889, 37, 161, 221; 38, 341, 415.

34. Ibid..

35. Ref. 15, p. 14

36. Os restantes membros da comissão foram João Baptista Schiappa Azevedo (1828-1882), um engenheiro formado na Escola Politécnica de Lisboa que, para além de estudos de hidrologia mineral, levou a cabo explorações mineralógicas no âmbito das suas funções no Ministério das Obras Públicas, e João de Andrade Corvo (1829-1890), escritor, agrónomo e político que desempenhou funções de professor no Instituto Agrícola de Lisboa.

37. Hofmann liderou um conjunto de alunos do Colégio Real de Química no estabelecimento de uma nova convenção na análise química de águas minerais em que as quantidades de sais em solução eram estabelecidas de acordo com as afinidades entre ácidos e bases, sendo que as bases mais fortes se presumiam combinadas com os ácidos mais fortes. A alternativa era estabelecer a composição considerando os sais por ordem de solubilidade.

38. Ref. 15, p. 17.

39. Ferreira, A. A.; Hydrologie Générale ou dissertation sur la Nature, les qualités e les usages des eaux naturelles e artificielles, minérales e potables, Imp. de P. Bourdier, Capiomont fils et cie.: Paris, 1867.

40. Gusmão, F. A. R. de; O Instituto 1872, 15, 120; uma recensão do livro publicado em 1871 pela Imprensa da Universidade As águas minerais de Moledo. Sua composição química, acções fisiológicas e efeitos terapêuticos, por Miguel Leite Ferreira Leão.

41. Uma citação da obra de Adriano Balbi, um geógrafo italiano que elaborou uma análise estatística de Portugal em 1820: Essai statistique sur le royaume de Portugal et d'Algarve, compare aux autres états de l'Europe.

42. Silva, J. S. e; $O$ Instituto $\mathbf{1 8 7 5}, 21,218$

43. A título de exemplo, $0,00122 \mathrm{~g}$ de ácido sulfúrico (sulfatos) combinam com $0,00099 \mathrm{~g}$ de potássio, originando $0,00221 \mathrm{~g}$ de sulfato de potássio; a restante quantidade de potássio determinada encontra-se combinada com cloro (cloreto) formando 0,00871 g de cloreto de potássio (Ibid., 259).

44. Ibid., p. 262

45. Silva, J. S. e; O Instituto 1876, 23, 69.

46. Ibid., p. 73.

47. Adicionando uma solução aferida de iodo em iodeto de potássio a uma amostra da água mineral, usando como indicador o amido que, reagindo com o iodo forma um complexo de cor azul intensa. O aparecimento desta cor servia para detectar o ponto final da análise titrimétrica.

48. Nos métodos gravimétricos, eram adicionadas soluções aferidas contendo a espécie reagente a uma determinada porção de água mineral, sendo a mistura colocada em repouso durante alguns dias, ao fim dos quais se procedia à análise do precipitado formado.

49. Withering referiu ter usado 8 libras médicas de água das Caldas com 16 onças cada quando, segundo Santos e Silva, o peso da libra médica em Inglaterra era de 12 onças. Outro problema era a conversão de onças e grãos para gramas, uma vez que a onça medicinal inglesa $(31,078 \mathrm{~g})$ e o grão $(0,065 \mathrm{~g})$ não coincidiam com a onça e o grão portugueses (respectivamente $28,68 \mathrm{~g} \mathrm{e} 0,04979 \mathrm{~g}$ ).

50. Oliveira Pimentel, formado em Matemática na UC, exerceu também o cargo de segundo director do Instituto Agrícola de 1857 a 1869, ano em que foi nomeado reitor da UC. Estudou a composição química de outras águas minerais portuguesas, tais como as do Gerês, em 1851, e as águas de Moura, no Alentejo, em 1850, cujos trabalhos foram publicados nas Memórias da Academia Real das Ciências de Lisboa.

51. Ibid., p. 165.

52. Silva, J. S. e; O Instituto 1879, 27, 330.

53. Ibid., p. 481.

54. Silva, J. S. e; Mota, R. S.; O Instituto 1883, 31, 279.

55. Ibid., p. 381.

56. Ref. 12, p. 188-189.

57. Lopes, A. L.; Águas minero-medicinaes de Portugal, Academia Real das Ciências: Lisboa, 1892.

58. Silva, A. J. F. da; O Instituto 1896, 43, 61.

59. Ibid., p. 65.

60. Ferreira da Silva fez uso de fórmulas químicas, nomeadamente $\mathrm{H}^{2} \mathrm{SO}^{4}$ e $\mathrm{Na}^{2} \mathrm{CO}^{3}$, o que não sucedia nos trabalhos de Santos e Silva. A escala de pH só seria inventada em 1909 pelo dinamarquês Sören Sörensen (1868-1839).

61. Ibid., p. 746

62. Ibid., p. 747-751.

63. Silva, A. J. F. da; O Instituto 1897, 44, 727.

64. Silva, A. J. F. da; O Instituto 1903, 50, 93.

65. Ibid., p. 163.

66. Rice, R. E. Em Sciences of the Earth - An Encyclopaedia of Events, People and Phenomena; Good, G. A., ed.; Garland Publishing, Inc.: New York, 1998, p. 833.

67. Ref. 4, p. 152-208.

68. Marques, J. E.; O Instituto 1879, 26, 517.

69. Ibid., p. 526.

70. Ibid., p. 533

71. Marques, J. E.; O Instituto 1879, 26, 561.

72. Ver Ref. 31, p. 203-223.

73. Cabral, J. O.; Colóquio/Ciências. Revista de Cultura Científica, 1998, 22,71 .

74. Silva, A. J. F. da; O Instituto $\mathbf{1 8 9 5}, 42,83$.

75. A título de exemplo, a detecção da presença de azoto amoniacal era feita com base no reagente de Nessler, ainda hoje em uso, cuja reacção era traduzida pela equação: $\mathrm{AzH}_{3}+2\left(\mathrm{HgI}_{2}, 2 \mathrm{KI}\right)+3 \mathrm{KOH}=7 \mathrm{KI}+2 \mathrm{H}_{2} \mathrm{O}+$ $\mathrm{Hg}_{2} \mathrm{AzI}, \mathrm{H}_{2} \mathrm{O}$

76. Silva, A. J. F. da; O Instituto 1895, 42, 449.

77. Pita, J. R.; Pereira, A. L.; Pinto, M. S.; Livro de Anais de Scientiarum 
Historia II - Encontro Luso-Brasileiro de História das Ciências, Universidade Federal do Rio de Janeiro/HCTE \& Universidade de Aveiro, 2009, p. 690

78. Lepierre, C.; O Instituto 1896, 43, 762 .

79. Lepierre, C.; O Instituto 1896, 44, 669.

80. Ref. 78, p. 773.

81. Ibid., p. 158.

82. Lepierre, C.; Seiça, V. J. de A.; O Instituto 1898, 44, 741.

83. Ibid., p. 96.
84. Ibid., p. 476.

85. Lepierre, C.; Lobo, N.; Movimento Médico 1902.

86. Ref. 77, p. 692-693.

87. Ibid., p. 689.

88. Quintela, M. M.; Hist. cienc. Saude 2004, 11, 244.

89. Ref. 11, p. 3.

90. Ref. 17, p. 32

91. Redinha, J. S.; Leitão, M. L. P.; Publ. Inst. Climat. Hidrol. UC, 1992$1993,32,5$. 